\title{
Pamięć historyczna w krajobrazie miasta Legnicy - dylematy wokół destruktywnego pobytu armii sowieckiej
}

\begin{abstract}
Die Anwesenheit der Sowjets in den Jahren 1945-1993 wirkt sich nicht nur auf den gesellschaftlichen, politischen, ökonomischen oder auch wirtschaftlichen Aspekt aus, sondern vor allem aber auch auf den urbanen Lebensraum. Vor immenser Bedeutung sind für die Einwohner verursachte Schäden von ökologischer Natur. Die weit verbreitete Praxis der Sowjets, nämlich die Verwüstung des Gutes, verursachte Massenbrände, Straffreiheit, wirkt sich zweifellos auf den Prozess der Dekapitalisierung der städtischen kommunalen Ressourcen und auch auf die räumliche Anordnung der Stadt aus.
\end{abstract}

Key words: Sowjets, Anordnung der Stadt aus

Piastowska Legnica leżąca w środkowej części Dolnego Śląska, nad rzeką Kaczawą stanowiącą lewy dopływ Odry, obecnie miasto na prawach powiatu grodzkiego, znana także jako: Lignica (dawniej), Lignitium (łac.), Liegnitz (niem.), Легни́ца (ros.), czy Lehnice (czes.) określana jest także niesłusznie kolokwialną nazwą „mała Moskwa”. To wyjątkowe historyczne miasto związane m.in. z Bitwą na Dobrym Polu (Bitwa 
z Mongołami pod Legnicą 9 IV 1241 r.), które wiąże tradycje kulturowe: Polski, Czech, Habsburgów, Prus, Niemiec, na podstawie postanowień konferencji poczdamskiej znajduje się w 1945 r. w granicach nowego terytorium Polski.

Zasadniczym zamierzeniem niniejszego opracowania jest próba zwrócenia uwagi na złożoną problematykę destrukcyjnego wpływu pobytu sowietów w latach 1945-1993 na stan i rozwój miasta. Ich obecność rzutuje nie tylko na aspekt społeczny, polityczny, ekonomiczny, czy gospodarczy, ale przede wszystkim na przestrzeń urbanistyczną. Znane są prace na temat zagospodarowania nieruchomości po wyjeździe sowietów, lecz jedynie dotyczące wybranych obiektów, dzielnic ${ }^{1}$, albo np. w ujęciu wyrządzonych przez sowietów szkód ekologicznych. Niemniej jednak przedmiotowa problematyka niewątpliwie jest zagadnieniem, które wymaga podjęcia dalszych, szerszych i wieloaspektowych badań. Niestety oprócz tego co nie daje się wymontować z domów i mieszkań opuszczający Legnicę sowieci zabierają ze sobą albo palą archiwalia i wszelką dokumentację (również redagowaną w Legnicy gazetę „Znamia Pobiedy” - „Знамя Победы”, czyli „Sztandar Zwycięstwa” swoiste narzędzie propagandy do kształtowania partyjnego i komunistycznego światopoglądu żołnierzy). Pozostały jednak nieliczne polskie zasoby archiwalne na przykład w Archiwum Akt Nowych w Warszawie znajduje się zespół akt nr 148 Delegatura Rządu PRL przy Dowództwie Pótnocnej Grupy Wojsk Armii Radzieckiej w Legnicy z lat 1945-1957². Dlatego swoistym novum do którego odnosi się autor tego swoistego

1 Zob. S. Sobota, Zagospodarowanie nieruchomości w legnickim „Kwadracie” po wyjeździe wojsk rosyjskich, „Przegląd geograficzny”, nr 83:2011, s. 531-541.

2 Ponadto zbiory i materiały fotograficzne gromadzi Archiwum Państwowe we Wrocławiu Oddział w Legnicy, a zachowały się w zespole „Urząd Wojewódzki w Legnicy, [1948-1975]1975-1998[1999]”. Fotografie (zasoby z lat 1992-1996) i dotyczą w większości podczas prac Zespołu ds. przejmowania mienia po JAR (Jednostkach Armii Radzieckiej), funkcjonującego na początku lat 90. Xx w. w strukturze Zakładu Administracyjno-Gospodarczego przy Urzędzie Wojewódzkim w Legnicy. 
szkicu w kontekście tematu krajobrazu miasta jest dotychczas szerzej nieprezentowana w literaturze przedmiotu unikatowa sowiecka mapa miasta będąca zarazem swoistym przewodnikiem po Legnicy 3. Ponadto istotnym motywem, który wpływa na podjęcie rzeczowego dyskursu staje się również polski film fabularny w reżyserii W. Krzystka „Mała Moskwa” (emitowany również w odcinkach przez TVP) oraz publikacja W. Konduszy „Mała Moskwa. Rzecz o radzieckiej Legnicy”. Trudno odnieść filmową odrealnioną adaptację fabularyzowania historii osadzoną i utrzymaną w melodramatycznej tonacji widzianą w pryzmacie reżyserskiej wyobraźni, która zasadniczo odbiega od rzeczywistości i faktów z życia okupowanego miasta. Do dzisiaj wśród Legniczan dominują ambiwalentne przekonania odnośnie pobytu wojsk i cywilów sowieckich zarówno w mieście, jak i w Polsce. Legnica jest wówczas miastem okupowanym ${ }^{6}$, inwigilowanym i zdominowanym przez armie sowiecką i jej cywilne służby.

\section{Wyzwolenie i nowa okupacja?}

Armia sowiecka wkracza do Legnicy 9 lutego 1945 r. Miasto z którego wcześniej wycofuje się regularna armia, broni niewielka liczba zmilitaryzowanych legniczan głównie funkcjonariuszy policji (ok. 200 osób). Nie napotyka się zatem wielkiego oporu na linii frontu. Sowieckie siły zbrojne zajmują miasto praktycznie bez walki. Ludność miasta,

3 „Mapa terytorialna obiektów garnizonu Legnica z lat 1975/1976”jest własnością osoby prywatnej pragnącej zachować anonimowość.

4 Polski film fabularny Mała Moskwa z 2008 r. w reżyserii i według scenariusza Waldemara Krzystka.

5 W. Kondusza, Mała Moskwa. Rzecz o radzieckiej Legnicy, Legnica 2006. Uzupełnione drugie wydanie wznowiono w $2011 \mathrm{r}$.

6 R. Żeleźny, Wojska radzieckie w Legnicy 1945-1993. Okupacja, kontrola, czy pobyt? Próba odpowiedzi, [w:] Wojska radzieckie w Polsce 1939-1993, red. S. Dąbrowski, K. Jaworska, W. Szetelnicki, Legnica 2013, s. 209-221. 
w tym "robotnicy przymusowi” czyli około 25 tysięcy mieszkańców stają wobec bezwzględności czerwonoarmistów. Zamek Piastowski zostaje całkowicie spalony („dopalał się do późnej jesieni”)7 na skutek celowego podpalenia czerwonoarmistów, pobliskie nieliczne domy uszkodzone przez ostrzał artyleryjski, bądź też bezmyślnie podpalane przez rozformowane oddziały żołnierzy. Wzniecane pożary nie są gaszone $\mathrm{z}$ uwagi na brak sprzętu ratunkowego oraz wody. W tym miejscu warto zaznaczyć, że kulminacja pożarów przypada na dni 1 i 9 maja, kiedy pijani sowieci świętują święto pracy i koniec wojny wzniecając bezmyślnie pożary. Żywioł niszczy głównie zabudowę centrum starego miasta. Tego typu sytuacje związane z celowymi podpaleniami trwają aż do jesieni 1945 roku$^{8}$. Rozpoczyna się masowa grabież, plądrowania mienia, brutalne gwałty, morderstwa. W tych miesiącach dochodzi do niekontrolowanych „rozstrzeliwań” mieszkańców, licznych morderstw ludności cywilnej, a nawet samobójstw. W piwnicach i na strychach mieszkańcy budują kryjówki przeznaczone dla kobiet, aby ochronić ich przed masowymi gwałtami oraz utratą życia. Ludność

7 Z. Szkurłatowski, Sytuacja miasta i jego mieszkańców w pierwszych powojennych latach, [w:] Legnica. Zarys monografii miasta, red. S. Dąbrowski, Wrocław-Legnica 1998, s. 408-409. Por. relacje Jürgena Gretschela w ramach projektu „Historia lokalna na przykładzie wybranych powiatów, miast i gmin”. Wykład „Kiedy większość staje się mniejszością”, oparty został na własnych oraz rodzinnych wspomnieniach (www.pro.legnica.pl - o2 IV 2015). J. Gretschel jest działaczem społecznym na rzecz pojednania Polaków z Niemcami. Pracował w PKs. W pierwszych wolnych wyborach do samorządów pracowniczych został przewodniczącym Rady pracowniczej PKs Legnica. W 1959 r. otrzymał dowód tożsamości cudzoziemca - obywatelstwo: bezpaństwowiec, narodowość niemiecka; z kartą stałego pobytu w Legnicy. W 1971 r. otrzymał obywatelstwo polskie. Uczył młodzież geografii, historii i umiłowania przyrody. W $1991 \mathrm{r}$. założył Niemieckie Towarzystwo Społeczno-Kulturalne w Legnicy, później został współzałożycielem Związku Niemieckich Towarzystw Społeczno-Kulturalnych w Polsce.

8 Od połowy 1945 r. „miesięcznie wybuchało średnio ponad 10 pożarów, których nie miał kto gasić. Miejską Zawodową Straż Pożarną powołano 5 maja 1945 r. i liczyła ona trzech strażaków” Z. Szkurłatowski, Sytuacja miasta i jego mieszkańców..., s. 409. 
miejscowa ginie „bez śladu”. Życie w mieście zamiera, nie działają zakłady elektryczne i wodociągowe. Rosjanie przystępują do konsumpcji tzw. „trafiejnego mienia” (ros. военных трофеев - wojenny łup) demontażu infrastruktury przemysłowej, silników elektrycznych i spalinowych, maszyn i urządzeń zwłaszcza do obróbki metali, kradzieży różnych narzędzi, a także radioodbiorników. Dopiero po kilku dniach od symptomatycznego „dnia wyzwolenia” z uwagi na własne potrzeby władze sowieckie wraz z niemieckimi jeńcami i technikami wznawiają zaopatrzenie miasta $\mathrm{w}$ wodę i energię elektryczną. Polski Pełnomocnik Obwodowy za zgodą sowietów dopiero 3 maja 1945 r. przejmuje miasto od „czerwonoarmijnego” komendanta wojennego, lecz ten fakt oczywiście nie oznacza oddania pełni władzy Polakom, czyli kilkuosobowemu zarządowi na prawach starostwa. Formalnie przekazanie władzy przypada na 16 maja $1945 \mathrm{r}$. i pomimo tego aktu sowieci w połowie lipca napływająca ludność wraz z administracją polską usuwają z lewobrzeżnej części miasta do dzielnic prawobrzeżnej Legnicy. Istotnym zdarzeniem związanym z konstytuowaniem nowej władzy jest czasowe przeniesienie z Trzebnicy do Legnicy 7 czerwca 1945 r. administracji województwa, lecz nie na długo. Zainicjowany proces stabilizacji zakłóca fakt rozwiązania w tym samym miesiącu frontów armii podporządkowując wszystkie sprawy dowództwu nowo utworzonej formacji - związku operacyjnego na terenie Polski: Północnej Grupy Wojsk Armii Radzieckiej (PGW, PGWAR; ros. Северная группа войск, СГВ) z głównym sztabem w Legnicy 9 . Zapada rozstrzygnięcie

9 Z. Szkurłatowski, Sytuacja miasta i jego mieszkańców..., s. 415-416; Jak podaje R. Fudali „Północna Grupa Wojsk Radzieckich (były II Front Białoruski) została utworzona 29maja $1945 \mathrm{r}$. Podstawę prawną jej powołania stanowił układ „O przyjaźni i współpracy Polski i zSRR” z 21 kwietnia 1945 r. W jej skład weszły: 43, 65, 52 armie i 4 Armia Lotnicza, a także przejściowo armie 18 i 60 oraz 1 Armia Gwardii znajdujące się dotąd w składzie iv Frontu Ukraińskiego." R. Fudali, Pótnocna Grupa Armii Radzieckiej w Polsce, „Przegląd Historyczno-Wojskowy", nr 12 (63)/4 (237): 2011, s. 225-234; B. Potyrała, Pólnocna Grupa Wojsk Armii Radzieckiej w Polsce i w województwie legnickim, „Szkice Legnickie”, nr 18:1986, s. 117-127. 
bez jakichkolwiek konsultacji, które determinuje pozycje miasta i jego mieszkańców. Powstaje miasto w mieście, miasto którego znaczna jego część nie jest uwzględniona na mapach. Miasto w którym wojska okupacyjne, często z bronią i obcych mundurach z czerwoną gwiazdą patrolują, poruszają się, żyją i bawią na koszt Polaków.

Zatem drugie pod względem wielkości dolnośląskie miasto, którego zasoby architektoniczne i substancja komunalna wraz infrastrukturą $\mathrm{z}$ wyjątkiem płonącego zamku w trakcie zajmowania miasta nie uległa zniszczeniu. Ze względu na dogodne strategiczne położenie geograficzne, istniejącą infrastrukturę i węzeł komunikacyjny (np. lotnisko, autostrada, nienaruszone obiekty militarne - tzw. „poniemieckie” obiekty garnizonowe wraz z koszarami, szpitale, budynki użyteczności publicznej, szkoły, teatr, ratusz, gmach sądu z więzieniem, obiekty zabytkowe np. „Akademię Rycerską” i in.) staje się główną siedzibą Północnej Grupy Wojsk Armii Radzieckiej przez 48 lat. Warto podkreślić fakt, że do miasta $\mathrm{w}$ pierwszych latach po zakończeniu działań wojennych przewozi się patriotów i żołnierzy polskiego zbrojnego „podziemia” AK oraz wIN, którzy przed zesłaniem do syberyjskich łagrów lub rozstrzelaniem są przetrzymywani i osadzeni w więzieniu przy ul. Gwarnej (dzisiaj już nieistniejącym - rozbiórki dokonuje się w 1996 r.) będącym we władaniu sowietów ${ }^{10}$. Legnica jest miastem w części wyłączonym i zakazanym dla Polaków - staje się miastem okupowanym, gdzie na mapach nie nanosi się ani obiektów użytkowanych przez wojska sowieckie oraz ich cywilne służby, jak i rodziny, ani ulic w „zakazanych rewirach” (il. 1-2). Część dzielnic należących do sowietów oddziela się zazwyczaj betonowym murem $z$ drutem kolczastym. Tereny te kolokwialnie nazywane „kompleksami” przekraczające liczbę stu obiektów są niedostępne dla ludności polskiej. Jednostkom tym przyporządkowywano również potoczne nazewnictwo, np. dla największego kompleksu w którym miesi się sztab wraz z kwaterami sowieckiej generalicji przylgnęła

10 Zob. J. S. Smalewski, Opowiedział mi Maks, Legnica 1994; W. Kondusza, Przewodnik po Legnicy Śladami Małej Moskwy, Legnica 2009, s. 6. 
nazwa „bolszoj kwadrat” (ros. большой квадрат), o dowództwu 4 armii lotniczej mówi się „wiertalotka” (ros. вертолет - vertolet - śmigłowiec), czy teren lotniska wraz z przylegającą infrastrukturą nazywano „wozduszka” (ros. воздух - vozdukh - powietrze), ponadto zaplecze magazynowe wraz z kompleksem żywnościowym i zaopatrzeniowym określa się „tri tołstiakov” (ros. три толстяков - trzy grubasy), natomiast batalion ochrony i obsługi sztabu (ul. Hutników i Sejmowa) „krasnyj gorod” (красный город - czerwone miasto / miasteczko), jak również jednostki łączności (radioliniowej) i remontowo-budowlane "prostokwaszyno" (ros. простокваша prostokvasha = zsiadłe mleko - ul. Złotoryjska). Sowieci zajmują ponad 470 budynków z liczbą ok. 3 tysięcy mieszkań zwłaszcza w elitarnych dzielnicach miasta np. „Tarninów” w reprezentacyjnych willach (byłych niemieckich lekarzy, adwokatów, urzędników itp.) w których lokuje się sowiecka kadra oficerska. Armia czerwona przejmuje na wyłączność, i tylko do swojej dyspozycji, ok. 1.200 obiektów o różnym przeznaczeniu, czyli przeszło $30 \%$ miasta (w jego przedwojennej zabudowie, to jest ok. $17 \mathrm{~km}^{2}$ powierzchni aglomeracji miejskiej w relacji do całkowitej powierzchni Legnicy wynoszącej wówczas $\left.56 \mathrm{~km}^{2}\right)^{11}$.

\section{Wymuszona koegzystencja}

Ponowienie należy odnieść się do bezspornego faktu, że miasto w 1945 r. po „wyzwoleniu” zostaje znacznie zniszczone przez swawolnych czerwonoarmistów. Powszechne praktyki stosowane przez sowietów, czyli dewastacje mienia, masowe podpalenia, bezkarność niewątpliwie wpływa na proces dekapitalizacji miejskich zasobów komunalnych ${ }^{12}$

11 W. Kondusza, Przewodnik po Legnicy..., s. 2-4; S. Kasprowiak, Co jest za tymi murami?, „Szkice Legnickie”, nr 15:1994, s. 129-136; Tenże, Kiedy zobaczymy „Kwadrat”?, „Szkice Legnickie”, nr 17:1995, s. 312-318.

12 Z. Szkurłatowski, Sytuacja miasta i jego mieszkańców..., s. 409-410; S. Dąbrowski, Pobyt i wycofanie północnej grupy wojsk radzieckich z Dolnego 
i zarazem układu przestrzennego Legnicy. Dopiero w kolejnych latach następuje proces odbudowy miasta, który trwa aż do dnia dzisiejszego. Przykładem jest zabytkowy obiekt Akademii Rycerskiej zlokalizowanej w centrum Legnicy, której koniec części rekonstrukcji i rewitalizacji skrzydła zachodniego przewidziany jest na 2016 r. Należy jednoznacznie zaznaczyć, że o zawładnięciu miasta przez armie sowiecką pozbawione jest jakichkolwiek podstaw prawnych. Wątpliwe argumenty o stacjonowaniu sowietów i ich rodzin oraz służb cywilnych ma dać wątpliwy układ o przyjaźni i współpracy Polski i zSRR z 21 kwietnia 1945 r. w kontekście utworzenia PGWAR.

Dopiero Rada Państwa PRL 17 grudnia 1956 r. podpisuje w Warszawie umowę między Rządem PRL a Rządem zsRR o statusie prawnym wojsk radzieckich czasowo stacjonujących w Polsce. Jakże bez jakiegokolwiek pokrycia są zawarte zapisy m.in. o czasowym stacjonowaniu jednostek wojsk radzieckich [które] $w$ Polsce $w$ niczym nie może naruszać suwerenności państwa Polskiego i nie może prowadzić do ich ingerencji $w$ wewnętrzne sprawy $P R L^{13}$. W zasadzie podczas pobytu sowietów w Legnicy nigdy nie zapada wyrok skazujący przez sądem polskim za przestępstwa i wykroczenia ${ }^{14}$ popełnione przez obywateli

Śląska, „Dolny Śląsk”, nr 1:1995, s. 79-82; A. Niedzielenko, Legnica jako ośrodek wojskowy [w:] Legnica. Zarys monografii miasta..., s. 614.

13 Art. 1 Umowy między Rządem PRL a Rządem zSRR o statusie prawnym wojsk radzieckich czasowo stacjonujących w Polsce (Dz U nr 29 z 29 maja 1957 r. poz. 127).

14 Warto przytoczyć część teksu opublikowany 30.12.2015 r. na portalu społecznościowym www.lca.pl przez P. Janturę, zus wciąż płaci poszkodowanym przez Sowietów: „Legnicki Zakład Ubezpieczeń Społecznych wypłaca obecnie 45 osobom renty odszkodowawcze dla poszkodowanych przez żołnierzy byłych wojsk radzieckich. Osobom poszkodowanym przez żołnierzy byłych wojsk radzieckich przyznawane były renty odszkodowawcze na podstawie orzeczeń komisji mieszanej (...) Wykonanie orzeczeń w zakresie wypłaty rent odszkodowawczych zostało powierzone zus. Po wycofaniu wojsk radzieckich w 1993 roku zgodnie z zasadą zachowania praw nabytych, renty odszkodowawcze wypłacane przed tą datą, są nadal wypłacane przez zus. W rejonie legnickim otrzymuje je 45 osób". 
ZSRR pomimo, że w art. 3 wspomnianej umowy wojska radzieckie przebywajace na terytorium $P R L$, osoby wchodzace $w$ skład tych wojsk oraz członkowie ich rodzin obowiązani sa szanować i przestrzegać prawa polskiego ${ }^{15}$. Sowieci nie rezygnują także z przywileju jaki posiadają, mianowicie dotyczącego umundurowania oraz posiadania i noszenia broni zgodnie z przepisami ustanowionymi w Armii Radzieckiej ${ }^{16}$. Jakże interesujący jest zapis kolejnych artykułów, niekorzystnych dla polskiej strony zawartych w przedmiotowej umowie. Niemniej jednak pełnym zaskoczeniem jest zdefiniowanie osób wchodzących w skład wojsk sowieckich, mianowicie: art. 18 - osoba wchodząca w skład wojsk radzieckich jest: a) żotnierz Armii Radzieckiej; b) osoba cywilna będqca obywatelem radzieckim i zatrudniona w jednostkach radzieckich $w P R L^{17}$. Na szczególną uwagę zasługuje sformułowanie pojęcia terenu stacjonowania wojsk sowieckich, uważanych za: teren wydzielony do dyspozycji wojsk radzieckich obejmujacy miejsca stacjonowania jednostek wojskowych wraz z placami ćwiczeń, strzelnicami, poligonami $i$ innymi obiektami, użytkowanymi przez te jednostki ${ }^{18}$. Należy dodać, że powyższa umowa jest również aneksowana i zmieniana na przykład na podstawie porozumienia z 18 czerwca 1958 r., czy z 2 sierpnia 1975 r.

Stacjonujący w granicach miasta kilkudziesięciotysięczne garnizony żołnierzy sowieckich, którzy w swoich mundurach i z bronią poruszają się po mieście. Ich pobyt dodatkowo wzmacnia podwojona liczbę rodzin i ludności cywilnej obsługujących swoje obiekty, czyli: magazyny, szkoły, przedszkola, sklepy, szpitale, kina, teatry, stadiony infrastrukturę (lotnisko, stację kolejową, samochodową bazę transportową $\mathrm{i}$ in.). Aktualnie z perspektywy czasu stacjonowanie i pobyt sowietów

$15 \mathrm{Dz}$ U nr 29 z 29 maja 1957 r. poz. 127.

16 Art.4, pkt.1 - „żołnierze wojsk radzieckich stacjonowanych na terytorium Polskiej Rzeczypospolitej Ludowej noszą przysługujące im umundurowanie oraz posiadają i noszą broń zgodnie z przepisami ustanowionymi w Armii Radzieckiej” (Dz U nr 29 z 29 maja 1957 r. poz. 127).

17 Dz U nr 29 z 29 maja 1957 r. poz. 127.

18 Dz U nr 29 z 29 maja 1957 r. poz. 127. 
w aspekcie degradacji obszarów miejskich należy jednoznacznie ocenić negatywnie. W następstwie ich obecności dla egzystencji miasta i jego rozwoju można wręcz mówić o regresie, także w zakresie bezpieczeństwa mieszkańców. Chodzi nie tylko o stan względnego spokoju i bezpieczeństwa poszczególnych legniczan, ale również o wyrządzanie szkód ekologicznych i degradacji środowiska naturalnego. Niestety teren dawnego lotniska oraz gleby ulega skażeniu. Skalę problemu prezentuje program rekultywacji terenów zdegradowanych. Zadaniem realizowanym od 1994 r. są prace związane przede wszystkim z czerpaniem paliwa z gruntu i zahamowanie migracji zanieczyszczeń. Ponadto dla zwiększenia efektywności podjęto sczerpywanie ropopochodnych substancji rozpoczynając od depresjonowania zwierciadła wody oraz oczyszczania koryta potoku Kopania wraz z zainstalowaniem na jego wylocie sparatora olejowego ${ }^{19}$. Pozostając przy problematyce bezpieczeństwa i ochrony środowiska warto wskazać także na szerszy raport dotyczący identyfikacji i wyceny sowieckich szkód ekologicznych w mieście, gdzie „obiekt Legnica” wraz z terenem jako poniemiecki kompleks mieszkalno-koszarowo-wojskowy przejęty w 1945 r. przez Wojska Federacji Rosyjskiej jest rozbudowywany do połowy lat osiemdziesiątych xx wieku. W skład obiektu wchodzi ponad 160 obszarów różnej wielkości i funkcji zlokalizowanych w różnych rejonach miasta oraz w jego najbliższej okolicy" ${ }^{20}$. Zatem skala poruszanego problemu jest znaczna. Efekty sowieckiej rabunkowej gospodarki obiektami i terenami widoczne są do dnia dzisiejszego.

19 Por. Projekt szczegółowego programu rekultywacji terenów zdegradowanych przez wojska federacji rosyjskiej na rok 1997 r. - Warszawa grudzień 1996 r., s. 7.

20 Główny Inspektor Ochrony Środowiska, Identyfikacja i wycena szkód ekologicznych spowodowanych przez stacjonujace w Polsce wojska Federacji Rosyjskiej. Raport końcowy, Warszawa - czerwiec 1994 [Raport końcowy został opracowany przez Zespół w składzie: Z. Kamieński, W. Derkacz, S. Kościelniak, E. Lenart, S. Neffe, W. Sobczyk, A. Spychała], s. 131. 
Inną istotną kwestią jest wypaczona misja pobytu armii sowieckiej w Polsce. W odniesieniu do realiów legnickich wypada wskazać, jak sowiecka wysoka kadra oficerska określa swój status w naszym kraju. Dochodzi do relacji pomiędzy wybranymi oficerami LwP i Mo z kadrą oficerską bloku Układu Warszawskiego zwłaszcza z zSRR i KGB oraz NRD i Czechosłowacji ${ }^{21}$. Według sowieckiej „gościnności” suto zakrapianej alkoholem komendant wojewódzki Milicji Obywatelskiej w Legnicy płk. M. Ochocki składając relację do Ministerstwa Spraw Wewnętrznych po jednych z „libacji” z oficerami armii sowieckiej stwierdza szefowie różnych grup operacyjnych PGWAR $i$ KGB potwierdzili, że sa w petni przygotowani do udzielenia Polsce internacjonalistycznej pomocy zgodnie z tym co powiedział Leonid Breżniew - bratniej Polski nie pozostawimy w potrzebie ${ }^{22}$. Zatem sowieci czują się w Polsce, w mieście, jak „u siebie” to uprawnia ich do niechętnych postaw zwłaszcza wobec tych, którzy w ich ocenie określani są „wrogami ustroju” i zSRR. Przy takim ideologicznym założeniu sowieci są przekonani, że pełnią swoistą misję „strzegąc pokoju i układu warszawskiego”. To przekłamane przekonanie daje sowietom „moralny” mandat na ingerencję w wewnętrze sprawy Polaków w różnych sytuacjach i wymiarach życia społeczno-politycznego. Codzienne trudności w poruszaniu komunikacyjnym, ograniczenia i strefy dzielące Polaków i obywateli zSRR w przestrzeni aglomeracji Legnicy stają się narzuconą rzeczywistością. Oczywiście Polacy wyrażają swoje niezadowolenie sprzeciwiając się okupacji sowieckiej demonstrując pod wstydliwym elementem upamiętniający pobyt sowietów - pomnikiem „Wdzięczności dla Armii

21 J. S. Smalewski, Wybrane problemy zachowań sojuszniczych - na podstawie kontaktów oficerów Wojska Polskiego z oficerami Armii Radzieckiej, [w:] Wojska radzieckie w Polsce 1939-1993, red. S. Dąbrowski, K. Jaworska, W. Szetelnicki, Legnica 2013, s. 463-472.

22 Instytut Pamięci Narodowej w Warszawie, Informacje z lat 1980-1981 dotyczace dowództwa, sztabu i niektórych jednostek Pótnocnej Grupy Wojsk Armii Radzieckiej opracowane przez komendanta wojewódzkiego mo w Legnicy pułkownika Marka Ochockiego, Archiwum osobiste: Czesław Kiszczak, sygn. IPN BU 3333/16. 
Radzieckiej”²3 (nazywanym również „pomnikiem przyjaźni”) którego sam twórca, rzeźbiarz Józef Gaza (także autor tzw. pomnika „czterech śpiących” na warszawskiej Pradze) zaproponował, aby zakopać go pod placem. Wydarzenia te mają miejsce na przykład w 1956 r., czy podczas manifestacji w: marcu 1968 r., grudniu 1970, sierpniu 1980 i 1982. Ostatnie wystąpienia i protesty przeciwko obecności wojsk okupacyjnych inauguruje transformacja ustrojowa i wolne wybory w $1989 \mathrm{r}$. W zasadzie fale sprzeciwów utrzymują się do opuszczenia Legnicy ostatniego eszelonu - transportu sowieckiego relacji Legnica-Brześć 16 września 1993 r. o godz. 21.32 wówczas kończy się etap niechlubnej okupacji i pobytu sowietów w Legnicy.

Reasumując należy podkreślić fakt, że obiekty w dzielnicach przeznaczonych tylko dla Rosjan w zasadzie nie są przez nich remontowane. Nowo zbudowane bloki mieszkalne tzw. „Leningrady” odbiegają od norm budowlanych mających zastosowanie w Polsce. Większość tych budynków oraz innych obiektów na przykład gospodarczych źle wpisuje się i komponuje w zabytkowe części i dzielnice miasta. Niemniej jednak począwszy od 1993 r. kolokwialnie nazywane „mieniem pojarowskie" (Jednostki Armii Radzieckiej) sukcesywnie jest zagospodarowywane i adoptowane do nowych realiów oraz warunków.

\section{Mapa - tylko dla obywateli ZSRS!}

Na potrzeby sowietów przyjeżdzających i mieszkających w Legnicy sporządza się mapę terytorialną obiektów garnizonu Legnica z lat 1975/1976. Na przedmiotowej mapie będącej odbiciem smutnej rzeczywistości

23 W miejscu, gdzie przed wojną stał pomnik Fryderyka Wielkiego, w szóstą rocznicę wkroczenia do Legnicy wojsk sowieckich 11 lutego $1951 \mathrm{r}$. odsłonięto monument „Wdzięczności dla Armii Radzieckiej”. Pomnik miał być podziękowaniem za oswobodzenie Legnicy z rąk niemieckich. Na temat pomnika szerzej A. Kowalczyk, O niektórych detalach z legnickiego pomnika wdzięczności, [w:] Wojska radzieckie w Polsce 1939-1993, red. S. Dąbrowski, K. Jaworska, W. Szetelnicki, Legnica 2013, s. 355-367. 
stacjonowania obcych i wrogich wojsk okupacyjnych nanosi się 145 obszarów (wraz z obiektami - „ перечень важных объектов” - spis ważnych obiektów) użytkowanymi zarówno przez armię radziecką w celach militarnych i gospodarczych, jak również cywilów (np. obiekty mieszkalne i użyteczności publicznej). Zawiera ona powszechnie stosowane i przyjęte standardowe umowne środki graficzne ( $\mathrm{tj}$. skalę w tym przypadku 1: 10 ooo, siatkę, podziałkę $\mathrm{i}$ in.) i legendę. $\mathrm{W}$ tym konkretnym przypadku wprowadza się oprócz znaków umownych do prezentacji treści mapy oraz możliwości odczytywania pomiaru różnych cech ilościowych i jakościowych swoistą „legendę” - przewodnik zawierający podstawowe dane o mieście i mieszkańcach, lecz nie tylko. Na mapie tematycznej stosownymi wprowadzonymi kolorami oznacza się charakter terenu oraz funkcję poszczególnych kompleksów i obiektów sowieckich. Niestety opis wspomnianych budynków i terenów jest niepełny. Należy w tym miejscu zwrócić uwagę na fakt lokalizacji jednostek i kompleksów, mianowicie Rosjanie posiadają i dysponują obiektami (bazami) położonymi zasadniczo przy głównych arteriach komunikacyjnych.

Informacja stanowiąca integralną część mapy zawiera kluczowe dane o Legnicy, mianowicie. Legnica - miasto $w$ PRL, centrum administracyjne Województwa Legnickiego, centrum rejonu wydobywczego (w okolicach wydobycie wegla brunatnego i miedzi), ważne centrum przemysłowe $i$ handlowe, węzeł dróg kolejowych i samochodowych. Położona na południowym zachodzie kraju, $55 \mathrm{~km}$ na północny zachód od wielkiego centrum przemysłowego Wrocławia, $55 \mathrm{~km}$ na północny wschód od granicy państwowej z Czechosłowacja i 77 km od granicy państwowej z NRD. Ludność Legnicy liczy 93 tysięcy mieszkańców (1982 r.); powierzchnia miasta $16 \mathrm{~km}^{24}$. Na podstawie tego opisu wnioskujemy, że mapa z lat 1975/76 jest aktualizowana w kolejnych latach i dane dotyczą stanu demograficznego z 1982 r. i jej druk następuje nie później niż w 1982 r. Ponadto zawarto informacje ogólne, czyli: Okolice

24 Tłumaczenie tekstu Ł. Skotnicka. 
miasta. Otoczenie w okolicach miasta równinne (wysokość bezwzględna 10o-18o m). Powierzchnia równiny łagodnie falista, miejscami pagórkowata, poprzecinana licznymi rzekami w szerokich dolinach, strumieniami i kanałami nawadniającymi, które stanowia główna przeszkodę dla ruchu pojazdów mechanicznych poza drogami. Wzgórza (wysokość względna $10-50 \mathrm{~m}$ ) posiadają łagodne wierzchołki i łagodne $\left(\right.$ do $\left.10^{\circ}\right)$, miejscami urwiste (wysokość urwiski $3-8 \mathrm{~m}$ ) zbocza. Wokolicach Legnicy są liczne doły (głębokość 3-5 m), jamy i kopce (4-5 m). Grunty w większości sa lessowe, ku pótnocy miejscami piaszczyste, $w$ dolinach rzek piaszczysto-galenitowe. Duża przegrodę wodna przy podejściu do miasta od pótnocnego wschodu stanowi żeglowna rzeka Odra. Szerokość rzeki 100-150 m, głębokość 3-4,5 m, szybkość przepływu o,6 m/ sek. Pozostałe rzeki nie sq duże; ich szerokość sięga $22 \mathrm{~m}$, głębokość do $2 \mathrm{~m}$, szybkość przepływu 0,2 0,7 m/sek. Dno jest piaszczyste lub muliste, grzaskie. Brzegi $w$ większości niskie (brzegi Kaczawy na niektórych odcinkach urwiste, wysokość 1-6 m), na wielu odcinkach umocnione wałami, w granicach miasta miejscami sa kanały. W okolicach miasta sa liczne nieduze jeziora i stawy o głębokości do $6 \mathrm{~m}$. Brzegi ich w większości sq niskie i łagodne, miejscami błotniste. Rzeki zamarzaja w końcu grudnia (na 15-4o dni), grubość lodu 15-30 cm. Pokrywa lodowa jest zmienna. W czasie cieplych zim nie tworzy się cala pokrywa lodowa. Wiosna (maj-marzec), gdy śnieg taje oraz latem $w$ czasie deszczów poziom wody w rzekach podnosi się o $2 \mathrm{~m}$ (np. na Odrze o $4 \mathrm{~m}$ ) powyżej dolnej granicy poziomu. Dolna granica poziomu występuje od czerwca do września, najniższe poziomy sq $w$ lipcu i sierpniu. Lasy iglaste (sosna) i mieszane (świerk, dąb) występuja w postaci niedużych masywów. Wysokość drzew 16-23 m, grubość pni o,20-0,30 m, odległość miedzy drzewami 3-5 m. Lasy sa czyste, bez podszytu. Występuja przesieki (szerokość 3-5 m). Ziemie uprawne w okolicach zajęte sq zasiewami pszenicy, buraków, ziemniaków; znaczne powierzchnie zajmuja sady owocowe i krzewy porzeczek. Sieć dróg samochodowych $w$ rejonie Legnicy jest dobrze rozwinięta i zapewnia ruch pojazdów mechanicznych $w$ ciagu roku $w$ dowolnym kierunku. Na południe od miasta przebiega autostrada Wrocław-Berlin (odcinek magistrali 
europejskiej E22); posiada ona betonowe płyty na nawierzchni o szerokości 8-9 m każda. Nawierzchnia ulepszonych szos to mieszanka bitumiczno-mineralna; szerokość jezdni wynosi 6-10 m, cała szerokość drogi 8-12 m. Nawierzchnia pozostałych szos to mieszanka bitumiczno-mineralna i bruk; szerokość jezdni 5-6 m, cała szerokość drogi 7-9 m. Pozostałe ulepszone drogi gruntowe (szerokość 4-8 m) sa profilowane, umocnione dodatkiem tłucznia, żwiru lub piasku. Drogi gruntowe położone na gruntach lessowych $w$ czasie deszczów rozmiękają i ruch na nich jest utrudniony. Mosty na drogach samochodowych są żelbetonowe (udźwig 10-3o ton), kamienne (15 ton) i drewniane 93-5 ton). W zamieszkałych punktach typu wiejskiego położonych w okolicach Legnicy żyje od kilku do kilkudziesięciu mieszkańców. W licznych zamieszkałych punktach działaja niewielkie zakłady przemysłu spożywczego (np. młyny) $i$ budowlanego (w tej liczbie cegielnie). Zabudowa zamieszkałych punktów $w$ rzędach ciasna lub rzadka niesystemowa. Znajduja się też oddzielne farmy. Nawierzchnia ulic magistralnych z masy bitumiczno-mineralnej, ich szerokość do $10 \mathrm{~m}$. Domy sa parterowe (rzadziej jednopiętrowe) kamienne. Większość zamieszkałych punktów jest zelektryfikowana i posiada łączność telefoniczną. Źródłem zaopatrzenia w wodę są studnie i rzeki. Jako miejsca do ukrycia w Legnicy moga służyć kopalnie rudy miedzi (rejon Bolesławiec-Złotoryja 15-25 km na zachód i południowy zachód od Legnicy, i rejon Lubin -Głogów 20-47 km na pótnoc od Legnicy), kopalnie wegla brunatnego (rejon Legnica-Lubin-Ścinawa) oraz kopalnie po miejsca po wydobyciu żwiru. Teren miasta podzielony jest przez rzeki na kilka części. Główna (duża) część miasta znajduje się w międzyrzeczu Kaczawy i Czarnej Wody. Plan miasta jest tu mieszany (radialny łaczy się z prostokątnym), zabudowa przeważa ciasna (miejscami nieprzerwana). Na krańcach miasta przeważa zabudowa rzadka; przy tym odcinki zabudowane występuja na zmianę z pustymi lub z sadami. Magistralne ulice miasta maja szerokość 15-25 m, pozostałe do $10 \mathrm{~m}$, sa pokryte asfaltem lub kamienna kostką. Domy przeważają kamienne 3-7 piętrowe Na południowy zachód od stacji kolejowej (obiekt 56) położone jest Stare Miasto - nieduża część starego miasta. Zachowat się tutaj plac ze starym 
zamkiem otoczonym klombami. W pobliżu starego miasta znajduje się poczta (obiekt 4o). Centrum administracyjne i urzędowe znajduje się na południe od Starego Miasta. Tutaj rozmieszczone są: Wojewódzka Rada Narodowa (obiekt 54), sąd (obiekt 62), bank (obiekt 7), różne sklepy. Zakłady przemysłowe znajduja się w różnych częściach miasta; największy zakład przemysłowy (huta miedzi) znajduje się na południowo-zachodnim krańcu miasta. W mieście jest dużo zieleni: znajduja się drzewostany wewnatrz dzielnic, trawniki, skwery, na krańcach miasta jest wiele sadów. Jest Instytut Politechniczny (obiekt 31) i Poligraficzny (obiekt 3o). W Legnicy znajduja się teatry, kluby, kina, muzea, stacje meteorologiczne (obiekty 58, 59). Obiekty przemysłowe i transportowe. Wiodąca gałęzia przemystu Legnicy jest kolorowa metalurgia (wytapianie miedzi). Rozwinięte jest budownictwo maszyn ( $w$ tym elektrotechnika), obróbka metali (produkcja konstrukcji stalowych, wyrobów metalowych, konstrukcji przemysłowych), przemysł materiałów budowlanych. Ważnymi obiektami przemysłowymi sa fabryki: huta miedzi (obiekt 16), fabryka kabli (obiekt 11 i 12), fabryka konstrukcji stalowych (obiekt 26), fabryka wyrobów metalowych (obiekty 17, 18, 19) oraz materiałów budowlanych (obiekty 27, 28, 29). Pracuje tartak (obiekt 15), zakład skórzany (obiekt14), zakład remontowy (obiekt 25), przędzalnie (obiekty 65, 66), szwalnia (zakład 67), zakład budowy instrumentów muzycznych, zakład przetwórstwa roślin leczniczych oraz różne zakłady rzemieślnicze (obiekty 6, 32, 33, 34). Przemysł spożywczy reprezentowany jest prze kombinat przetwórstwa mięsnego (obiekt 37), mleczarnię (obiekt 20), i inne zakłady (obiekty 22, 23, 24). Jest drukarnia (obiekt 64). W Legnicy jest wiele magazynów (obiekty 15, 43, 44, 45-48, 51, 52, 53, 49, 50), wśród nich obiekt 51 - magazyn paliw i smarów; dwa elewatory (obiekty 68, 69).

Węzeł kolejowy Legnica posiada kilka stacji. Największa z nich pasażerska i transportu ładunków (obiekt 56) ma rozwinięte zaplecze drogowe i magazynowe; działa lokomotywownia (obiekt 8). Gospodarstwo komunalne, środki łączności i instytucje medyczne. Energię elektryczna Legnica otrzymuje z jedynego systemu energetycznego kraju, do którego podłączona jest też miejscowa ciepłownia zaopatrująca miasto w ciepła 
wodę. Miasto posiada gazociag; gaz dostarczany jest $z$ miejscowego zakładu gazowniczego oraz gazociagami z zakładów koksowniczych Wrocławia, Turoszowa i Wałbrzycha. Większość mieszkalnych rejonów miasta posiada wodociagi; woda do sieci wodociagowej dostarczana jest ze stacji wodociagowej (obiekt 55). Działa oczyszczalnia ścieków (obiekt 60 i 61). Na krańcach miasta źródłem zaopatrzenia w wodę sq studnie. Kanalizacje posiada 50 \% zasobów mieszkalnych miasta. Legnica posiada łączność telefoniczna i telegraficzna z pozostałymi miastami kraju. $W$ mieście działa kolka szpitali i innych instytucji sanitarno-medycznych.

Należy w tym miejscu zadać retoryczne pytanie w jakim celu obywatelom zSRR którzy przyjeżdżają bądź przebywają w Legnicy potrzebne są tak szczegółowe dane na przykład o stanie dróg, czy warunkach atmosferycznych lub infrastrukturze?

\section{Konkluzja}

Do 1956 r. stacjonowanie wojsk sowieckich oraz rosyjskiej ludności cywilnej na terytorium Polski nie jest prawnie uregulowane i praktycznie pozostaje poza wszelką kontrolą. Oczywiście władze PRL również w kolejnych dekadach faktycznie nie ma żadnego wpływu na jakiekolwiek administrowanie i życie sowietów w Polsce. Niewątpliwie pobyt zarówno uzbrojonej sowieckiej armii oraz co najmniej podwojonej liczby „cywilów” nie licząc dzieci i młodzieży na terenie miasta wywiera niezatarty wpływ i piętno w krajobrazie Legnicy (np. brak mieszkalnej zabudowy wielokondygnacyjnej w pasie i strefie bezpieczeństwa sowieckiego lotniska). Sowiecka armia dysponuje wspaniałą infrastrukturą w sumie 1200 obiektami zlokalizowanymi na powierzchni 17 kilometrów kwadratowych do której Polacy nie mają dostępu bądź w sytuacjach wyjątkowych są jedynie tolerowani. Życie w mieście nie jest dobrą opartą na podstawie wzajemnego poszanowania koegzystencją. Zdarzają się przypadki nawiązywania relacji z sowietami głównie na płaszczyźnie handlowej (tzw. „czarnego rynku”) i dostępu do ich 
dobrze zaopatrzonych sklepów spożywczych, gdzie Polacy nie mają wstępu. Przeważnie tego typu obiekty lokalizowane są w dzielnicach sowieckich strzeżone przez uzbrojonych żołnierzy radzieckich. Można wyrazić tezę, że mieszkańcy miasta nie posiadając innej alternatywy poddają się procesowi adaptacji i przystosowania do istniejącej rzeczywistości. Ironiczne stwierdzenia Legniczan „armia radziecka z nami od dziecka” uzewnętrznia problem i brak możliwości dokonania przemiany w mieście. Dopiero zainicjowana w Polsce droga przemian i transformacji w 1989 r. umożliwia rozwiązanie kwestii sowieckiej i ich pobytu w naszej Ojczyźnie. Dwustronne negocjacje rozpoczynają się w Moskwie w grudniu 1990 r. Rozpad bloku militarnego pod nazwą „Układ Warszawski” w połowie 1991 r. i w grudniu ZSRR umożliwia dalszy pomyślny choć trudny przebieg rozmów rządów obu krajów ${ }^{25}$. Zwierzchnictwo na PGWAR przejmuje Federacja Rosyjska. Skarb Państwa odzyskuje w większości zdewastowane obiekty formalnie od 16 września 1993 r., które stanowią 1/3 starej, historycznej, secesyjnej, centralnej zabudowy części miasta ${ }^{26}$. Dodając należy wspomnieć, że z chwilą opuszczenia Legnicy przez ugrupowania i formacje bojowe, pozostają jeszcze jednostki likwidacyjne, których głównym zadaniem jest zabezpieczenie tranzytu wojsk sowieckich wycofujących się z terytorium Niemiec do Rosji.

W Legnicy istnieje wiele miejsc i pamiątek wiążących się z okupacją sowiecką począwszy od dawnych stanowisk strzeleckich rozmieszczonych w strategicznych punktach miasta, poprzez obiekty wymagające gruntownych remontów i napisów cyrylicą wyrytych na wielu budynkach, aż po kwatery na cmentarzu komunalnym nad którymi góruje

25 Por. Układ między Rzeczpospolita Polska a Federacja Rosyjską w sprawie wycofania wojsk Federacji Rosyjskiej z terytorium Polski, Moskwa, 22 maja 1992 r. (Archiwum Państwowe we Wrocławiu Oddział w Legnicy, Urząd Wojewódzki w Legnicy, sygn. 10/197, s. 7-11, 44-45).

26 S. Jasak, Zagospodarowanie nieruchomości Skarbu Państwa przejętych od wojsk Federacji Rosyjskiej (na przykładzie Legnicy), „Szkice Legnickie”, nr 20:1999, s. 175-182. 
wzniesiony w 1972 r. monument dedykowany żołnierzom sowieckim, którzy zginęli, „wyzwalając ziemię legnicką”.

\section{Bibliografia}

Dąbrowski S., Pobyt i wycofanie pótnocnej grupy wojsk radzieckich $z$ Dolnego Śląska, „Dolny Śląsk” nr 1:1995, s. 79-82.

Fudali R., Północna Grupa Armii Radzieckiej w Polsce. „Przegląd Historyczno-Wojskowy", nr 12 (63)/4 (237): 2011, s. 225-234.

Jasak S., Zagospodarowanie nieruchomości Skarbu Państwa przejętych od wojsk Federacji Rosyjskiej (na przykładzie Legnicy), „Szkice Legnickie", nr 20:1999, s. 175-182.

Kasprowiak S., Co jest za tymi murami?, „Szkice Legnickie”, nr 15:1994, s. $129-136$.

Kasprowiak S., Kiedy zobaczymy „Kwadrat”?, „Szkice Legnickie”, nr 17:1995, s. 312-318.

Kondusza W., Mała Moskwa. Rzecz o radzieckiej Legnicy, Legnica 2006.

Kondusza W., Przewodnik po Legnicy Śladami Małej Moskwy, Legnica 2009.

Kowalczyk A., O niektórych detalach z legnickiego pomnika wdzięczności, [w:] Wojska radzieckie w Polsce 1939-1993, red. S. Dąbrowski, K. Jaworska, W. Szetelnicki, Legnica 2013, s. 355-367.

Niedzielenko A., Legnica jako ośrodek wojskowy [w:] Legnica. Zarys monografii miasta, red. S. Dąbrowski.

Potyrała B., Północna Grupa Wojsk Armii Radzieckiej w Polsce i w województwie legnickim, „Szkice Legnickie”, nr 18:1986, s. 117-127.

Smalewski J. S., Opowiedział mi Maks, Legnica 1994.

Smalewski J. S., Wybrane problemy zachowań sojuszniczych - na podstawie kontaktów oficerów Wojska Polskiego z oficerami Armii Radzieckiej, [w:] Wojska radzieckie w Polsce 1939-1993, red. S. Dąbrowski, K. Jaworska, W. Szetelnicki, Legnica 2013, s. 463-472. 
Sobota S., Zagospodarowanie nieruchomości w legnickim "Kwadracie” po wyjeździe wojsk rosyjskich, „Przegląd geograficzny”, nr 83:2011, S. 531-541.

Szkurłatowski Z., Sytuacja miasta i jego mieszkańców w pierwszych powojennych latach, [w:] Legnica. Zarys monografii miasta, red. S. Dąbrowski, Wrocław-Legnica 1998, s. 408-409.

Żeleźny R., Wojska radzieckie w Legnicy 1945-1993. Okupacja, kontrola, czy pobyt? Próba odpowiedzi, [w:] Wojska radzieckie w Polsce 1939-1993, red. S. Dąbrowski, K. Jaworska, W. Szetelnicki, Legnica 2013, s. 209-221. 


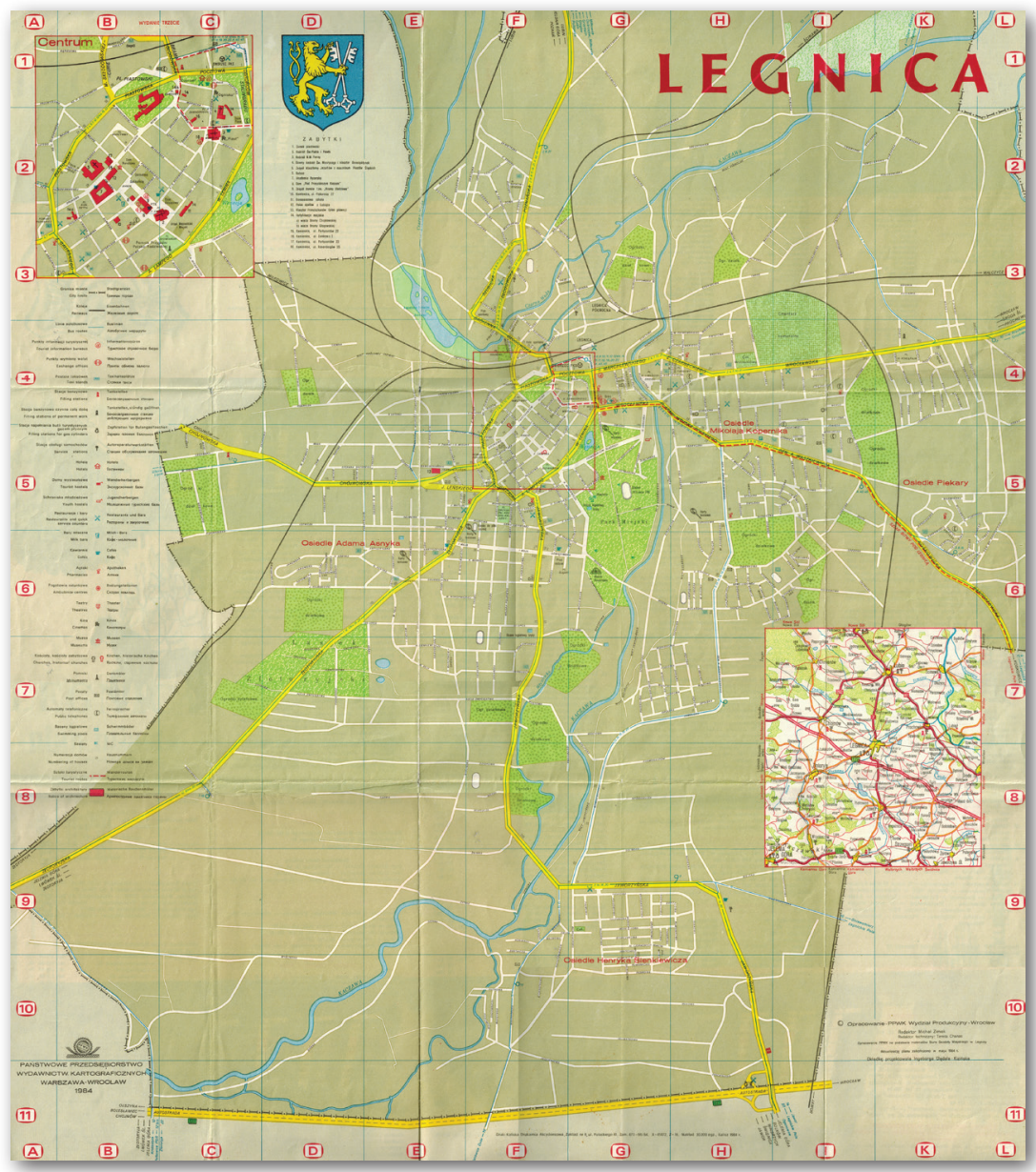

il. 1 - mapa miasta z 1984 r. (brak naniesionego na mapie m.in.: lotniska, dzielnicy tzw. „kwadratu”, ulic i magazynów na obszarach zajmowanych przez sowietów). M. Zimek (red.) PPWK (oprac.), Legnica: plan miasta, Wrocław 1984. 


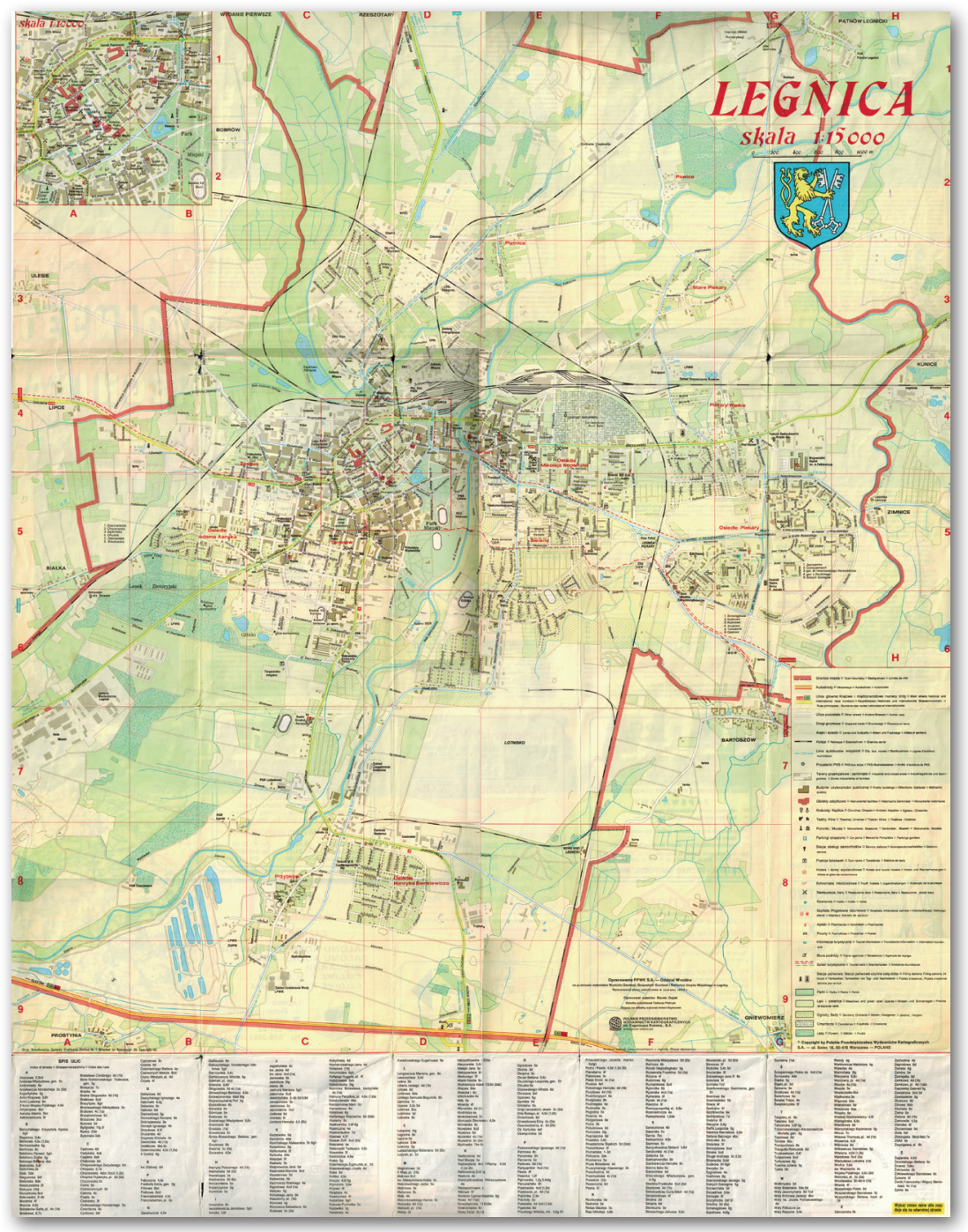

il. 2 - pierwsza po transformacji ustrojowej „publiczna” mapa Legnicy z 1992 r. (z uwzględnieniem m.in.: lotniska, dzielnicy tzw. „kawadrat” i innych terenów okupowanych przez sowietów).

M. Dajek (oprac.), Legnica: plan miasta, CIP - Biblioteka Narodowa - Wrocław 1992. 